\title{
Energy Recycling - Landfill Waste Heat Generation and Recovery
}

\author{
Robert J. Grillo
}

Published online: 16 September 2014

(C) Springer International Publishing AG 2014

\begin{abstract}
It is well known in the solid waste industry that waste disposed in landfills generates heat. Until recently, efforts to recover the heat and use landfills as a heat source did not exist. Landfill heat is generated from degradation of various waste types as a result of chemical and biological processes. Waste temperatures in landfills can range from $20^{\circ} \mathrm{C}$ to over $90^{\circ} \mathrm{C}$ under certain conditions. The principles of geothermal heating systems can be applied to landfills to recover the heat for space heating and other purposes. Landfill based geothermal systems are more efficient than ground based systems because ambient temperatures in landfills are warmer than the ground by $10^{\circ} \mathrm{C}$ to $45^{\circ} \mathrm{C}$. Case studies indicate the high level of efficiency and cost effectiveness of landfill based geothermal systems, with simple payback periods in the range of 4 to 7 years when compared to conventional space heating technology.
\end{abstract}

Keywords Landfill Heat - Heat Recovery · Geothermal . Methanogenesis - Ash Landfills · Aerobic Landfills . Hot Landfills - Subsurface Reaction Landfills

\section{Introduction}

Chemical and biologic processes in solid waste landfills lead to the exothermic decomposition of the waste. These processes vary with the type and constituents of solid waste (I.e., municipal solid waste, waste-to-energy ash residue, industrial wastes, etc.), and how landfills are operated. This paper reviews the mechanisms of heat generation in landfills, strategies to recover the heat, and case studies where landfill waste has been used as a heat source.

R. J. Grillo $(\bowtie)$

CMA Engineers, Inc., Ten Free Street, Portland, ME 04101, USA

e-mail: rgrillo@cmaengineers.com

\section{Solid Waste Landfill Heat Generation}

Municipal Solid Waste Landfills - Anaerobic Operation

The organic fraction of municipal solid waste (MSW) disposed in landfills is decomposed through biologic processes that proceed in sequential phases [1]. These include:

- Hydrolysis of carbohydrates, fats, and proteins - exothermic reactions occur for several days [2] during initial waste placement under aerobic conditions;

- Acidogenesis of sugars, fatty acids, and amino acids occurs over a period of approximately 10 to 150 days [2] during the transition from aerobic to anaerobic conditions as the oxygen present in the waste is depleted;

- Acetogenesis of carbonic acids and alcohols, hydrogen, carbon dioxide, and ammonia - occurs over a period over three months to many years depending on water content [2] at the onset of anaerobic conditions, and is typified by the growth of acidogenic bacteria;

- Methanogenesis of hydrogen, acetic acid, and carbon dioxide - occurs over decades [2] under anaerobic conditions as methanogenic bacteria convert the intermediate products from the prior phase to methane, carbon dioxide, and hydrogen sulfide. The optimum temperature for methanogenesis takes place between $35^{\circ} \mathrm{C}$ and $40^{\circ} \mathrm{C}$ for mesophilic bacteria, and between $50^{\circ} \mathrm{C}$ to $60^{\circ} \mathrm{C}$ for thermophilic bacteria $[3,4]$.

Currently active regional or commercial landfills are typically operated for decades because of the large investment made in the infrastructure to support such facilities and the difficulty of siting new facilities. Given these long operating periods, the final methanogenic phase of biological decomposition predominates over the precursor phases throughout most of the waste mass for conventionally operated MSW landfills. 
Methanogenic decomposition is an exothermic process resulting in elevated temperatures within the landfill. Temperatures are usually highest within the central mass of the waste, with lower temperatures near the landfill perimeter and surface, where heat is lost to the atmosphere, and at the base liner where the heat from the waste is lost to the cooler engineered base of the landfill and natural ground [5]. The MSW waste temperatures should remain elevated as long as methanogenesis is taking place. Ultimately, over decades, waste temperatures will slowly decrease and stabilize at ground temperature.

Landfills operated with leachate collection and provisions to shed rain and snowmelt (conventional "dry" landfills) are generally cooler than landfills where liquids are added or leachate is allowed to mound (wet landfills) [6]. Temperatures of the lining system were monitored at two landfill cells near Philadelphia, USA [7]. One cell was operated as a dry landfill, and the other as a wet landfill. In the dry cell, temperatures at the liner held at a constant $20^{\circ} \mathrm{C}$ for the first 5.5 years of operation, and then increased to 30 to $37^{\circ} \mathrm{C}$ for the remaining 4.5 years of the study. Temperatures in the wet cell began at 25 to $28^{\circ} \mathrm{C}$ and rose to 41 to $46^{\circ} \mathrm{C}$ during the 3.5 years of study.

The spatial and temporal variations of temperature within landfill waste was studied at landfills located in Michigan, New Mexico, and Alaska, USA, and British Columbia, Canada [8]. Maximum stable temperatures in the waste were $57^{\circ} \mathrm{C}, 35^{\circ} \mathrm{C}$, and $42^{\circ} \mathrm{C}$ in the Michigan, New Mexico, and British Columbia landfills, respectively. The maximum stable temperature in the Alaska landfill was $23^{\circ} \mathrm{C}$, although this waste was relatively younger ( 2.3 years old) than the other landfills (5.5 to 7 years old), and temperatures were rising in the Alaska landfill at the conclusion of the study. High temperatures were generally observed within central regions of the waste as measured both vertically and horizontally. Lower, yet elevated, temperatures were recorded at the base lining systems. Temperature magnitude and variation near the surface and perimeter reflected ambient air temperatures, whereas the temperatures in central and lower portions of the waste were relatively stable.

\section{Municipal Solid Waste Landfills - Aerobic}

Experimental studies at two landfills in Georgia, USA have demonstrated the viability of operating MSW landfills under aerobic conditions [9•]. Aerobic biodegradation is similar to composting, and is accomplished by adding air and moisture in carefully controlled proportions. Aerobic digestion emissions consist primarily of carbon dioxide. Operating landfills under aerobic conditions substantially reduces or eliminates generation of methane, other organic compounds, and odor, and rapidly degrades and stabilizes the waste.
Operating experience indicates that introducing large quantities of air into an MSW landfill will inhibit methanogenesis, raise waste temperatures to $70^{\circ} \mathrm{C}$ or higher, and potentially ignite the waste. At the Georgia experimental sites, leachate was recirculated into the waste using vertical wells and pressurized drip irrigation hoses. These liquids were added to facilitate aerobic degradation and to cool waste temperatures to an operating range of $40^{\circ} \mathrm{C}$ to $60^{\circ} \mathrm{C}$. Air was injected into the waste using electric blowers or an air compressor connected to vertical wells.

The first commercial scale aerobic MSW landfill has begun operation at the Regional Municipality of Wood Buffalo in Alberta, Canada (http://www.fortmcmurraytoday.com/2012/ $10 / 31$ /sustainable-landfill-to-reduce-greenhouse-gasemissions). The first phase of the aerobic gas management plan is expected to reduce emissions of methane in carbon equivalents by 1.2 to 1.5 million tons over a four year period relative to a conventional anaerobic landfill.

\section{WTE Ash Residual Landfills}

There are currently 86 waste-to-energy (WTE) facilities in the USA (http://www.epa.gov/solidwaste/nonhaz/municipal/wte/ index.htm). Worldwide, about 130 million tons of MSW is combusted in 600 WTE facilities (http://www.seas.columbia. edu/earth/papers/global_waste_to_energy.html). The WTE method of MSW management is preferred over landfilling waste in Europe, in Japan, and in many other countries. After combusting the MSW for energy recovery, approximately 10 to $25 \%$ of the volume remains as ash residuals. These residuals are typically landfilled in ash monofills.

Ash temperatures within a WTE residual landfill in New Hampshire, USA were reported to be as high as $69^{\circ} \mathrm{C}$ [10]. The residuals include a mixture of bottom ash and fly ash. The elevated ash temperatures were attributed to oxidation reduction reactions of aluminum and other metals present in abundant quantities in the ash, hydration of unreacted lime from flue gas air pollution controls, and other exothermic chemical reactions. Elevated ash temperatures have persisted over a 20 year period in portions of the landfill (Author's experience).

Similar ash temperatures were measured at a WTE bottom ash landfill in Ingolstadt, Germany [11]. Ash temperatures at various levels in the landfill were measured over a three year period. Maximum temperatures of $70^{\circ} \mathrm{C}$ were observed near the vertical center of the ash. A maximum ash temperature of $46^{\circ} \mathrm{C}$ was observed at the landfill base.

"Hot" Landfills

Increasing numbers of conventionally operated MSW landfills are reporting the occurrences of unusually hot temperatures within the waste [12•]. Typically, observations of hot 
temperatures are first made during drilling to install vertical gas wells through the waste. The elevated temperatures can be deep into the landfill and are attributed to certain subsurface chemical reactions, and not the result of landfill fires. Typical symptoms of landfill fires are missing, such as isolated and shallow settlement; occurrence near areas that potentially could provide a pathway for oxygen intrusion, such as gas wells; evidence of char, smoke and flame; and combustion byproducts in gas emissions.

Symptoms of the subsurface reactions include:

- Gas constituents change as carbon dioxide increases to up to $75 \%$ of the gas volume; methane generation decreases and stops; and hydrogen and carbon monoxide appear in the gas;

- Gas temperatures increase from $45^{\circ} \mathrm{C}$ to up to $90^{\circ} \mathrm{C}$ or higher [13•];

- Gas wellhead pressures can exceed 100 kilopascals gage;

- Gas generation rates can increase by a factor of 4 or 5;

- Increase in entrained moisture in landfill gas and increased leachate and condensate production;

- Differential settlement rates increase to levels higher than historical average;

- Increase in reduced sulfur compound odors;

- Leachate collection system fouling and clogging.

The cause of the subsurface reactions is not known at this time. Several of the affected landfills accepted aluminum dross wastes, but not all of them. Oxidation reduction reactions of aluminum are exothermic and could partially explain the onset of elevated waste temperatures. The subsurface reactions tend to spread throughout the landfill over time. It typically can take several years for the reactions, once detected at a single location, to spread throughout a landfill [12•].

The pattern of subsurface reaction development suggests that the exothermic chemical reactions of a particular waste may raise waste temperatures, which in turn appears to alter the population of bacteria in the landfill. Methanogenic mesophile and thermophile bacteria become dormant or perish, and hyperthermophilic bacteria, which thrive in temperatures between $60^{\circ} \mathrm{C}$ and $100^{\circ} \mathrm{C}$, likely grow and prosper. These bacteria and other reactions at the elevated temperatures produce gases consisting of carbon dioxide, carbon monoxide, and hydrogen, but not methane. It appears that these reactions may also generate additional heat, raising waste temperatures above normal levels. This in turn expands the "hot" zone, and areas favorable for additional hyperthermophilic bacteria growth, until the entire landfill is converted to a high temperature environment.

These subsurface reactions present many operational challenges [13•]. The heat, pressure, and volume of the landfill gas from affected areas exceed the material property limits of existing high density polyethylene landfill gas collection systems. Required replacement systems would consist of a denser array of wells and piping consisting of steel. A greatly accelerated schedule of pipe jetting and pump maintenance is required to keep the leachate collection system clear of scale, concretions, and corrosion. Control of odors and non-methane organic compound (NMOC) releases becomes difficult, due to increased gas production rates and decreased methane production. Odors and NMOCs are normally destroyed by combustion of the landfill gas. With little or no methane in the gas it cannot be burned without either blending in conventional landfill gas from unaffected portions of the landfill, or adding propane or natural gas as a supplemental fuel to facilitate combustion. Landfill gas from subsurface reaction sites is hot and saturated with moisture. The gas must be cooled and dewatered prior to treatment. Hydrogen has a much higher flame propagation rate than methane and can cause destructive flashback without specifically designed and more robust flame arresters.

Laboratory research, conducted on waste samples from a landfill in Hawaii, USA, documented changes to the bacterial population when waste temperatures were raised from typical landfill temperatures of $54^{\circ} \mathrm{C}$, to the $82^{\circ} \mathrm{C}$ temperatures representative of subsurface reaction sites [14•]. The experiments were able to produce landfill gas volume and constituents matching those of subsurface reaction sites after the waste samples were heated. The waste samples were subsequently cooled back to $54^{\circ} \mathrm{C}$, and gas production returned to the normal volume and proportions of methane and carbon dioxide. This behavior suggests that the methanogenic bacteria had been dormant, rather than having perished when subjected to the higher temperatures. Further, it appears that cooling the waste could potentially control the subsurface reactions and return the landfill to normal operating conditions. The conventional method to cool the waste (e.g., injecting leachate, water, or other liquids), however, is not feasible at these sites, as liquid injection would flood the gas collection systems needed to collect and control gas releases.

\section{Heat Recovery Strategies}

The principles of geothermal heating systems can be applied to landfills to recover heat. Geothermal systems typically consist of a heat exchanger and a heat pump. Heat exchangers can be closed loop systems where fluid is pumped through a piping system; or open systems where water is extracted from a surface water body or open borehole, processed through a heat pump, and then discharged back into the water body, or a recharge open borehole. Three types of geothermal heating systems are shown on Fig. 1. 
Fig. 1 Types of Geothermal Heating Systems. http://energy. gov/energysaver/articles/ geothermal-heat-pumps
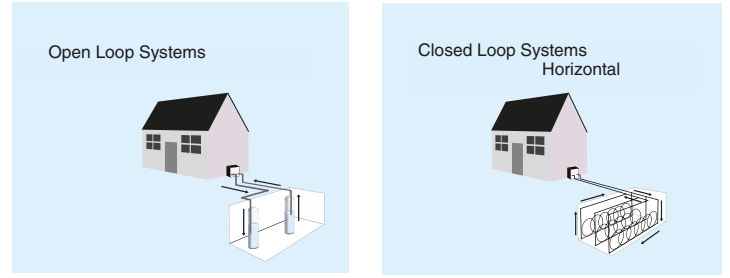

$\stackrel{\text { Legend }}{\longrightarrow}$ Piping and Flow Direction

\section{Ground Coupled Heat Exchangers - Closed Loop}

Closed loop Ground Coupled Heat Exchangers (GCHX) have the capability to recover significant quantities of heat from landfills. Conventional geothermal heating systems can extract heat from the ground using closed loop systems installed in vertically drilled wells, or horizontal piping loops installed in trenches. Both types of systems are viable for landfill heat recovery.

Conventional geothermal systems recover latent heat from the ground having background soil or rock temperatures in the range of $10^{\circ} \mathrm{C}$ to $15^{\circ} \mathrm{C}$ in most temperate regions. As geothermal systems remove heat from the ground for space heating purposes, ground temperatures typically fall to near $0^{\circ} \mathrm{C}$ in the winter months. As a result, conventional geothermal system design assumes a lower bound soil temperature of $0^{\circ} \mathrm{C}$ for system sizing and energy use projections. Ground temperatures in the summer rebound to ambient temperatures through solar radiation and exposure to warm air temperatures, or by direct heat input by operating the geothermal systems as air conditioners to cool interior space.

From a heating perspective, landfill heat recovery systems offer large efficiency advantages over conventional ground based geothermal systems because in-situ temperatures are much higher, in the range of $20^{\circ} \mathrm{C}$ to $60^{\circ} \mathrm{C}$ versus $10^{\circ} \mathrm{C}$ to $15^{\circ} \mathrm{C}$, and landfills generate heat rather than relying on heat from the sun to raise ground temperatures. Further, space heating is feasible without using a heat pump provided the return GCHX supply temperature exceeds $35^{\circ} \mathrm{C}$ [15•]. This temperature level is exceeded within most landfills, and foregoing a heat pump simplifies the heating system and reduces capital and operating costs.

Use of the extracted heat for space heating is feasible provided that its end use is proximate to the landfill, as heat loss will occur in piping between the landfill and the heated structure. Landfill related structures such as pump stations, scale houses, administrative, equipment storage, and maintenance buildings could benefit from the landfill heat in lieu of conventional space heating systems. In addition, a landfill heat source could be used to heat pavement to melt ice and snow in key areas such as scale approaches. Further, adjacent commercial/industrial parks or greenhouses are promising candidates for heat from a landfill source. A relatively small horizontal loop GCXH system installed in a landfill in New Hampshire, USA, consisting of $32 \mathrm{~mm}$ diameter piping spaced at 0.6 meters over an 840 square meter area pumping at 250 liters/minute, could extract heat at a peak load of 73 $\mathrm{kW}$, which is enough energy to heat four residences [15•].

Closed loop GCHX systems can be viable in a number of configurations in landfills:

- Vertical wells are suited to landfills that are at, or near, final grades, or are already closed. The wells can be installed through the center of the waste where the temperatures are highest, and in areas of the landfill not being actively operated. Although these wells are subject to damage from settling waste, experience with vertical gas collection wells suggests a long-term viability for these wells. Damaged wells can be repaired or replaced as they are terminated and accessed at the surface. The effective heat transfer radius of each well is expected to be limited, requiring a large number of wells for substantial or comprehensive heat recovery. Each well installation is costly, estimated to be in the range of US\$350 to US\$500 per meter of length (Author experience with gas collection well installation construction prices). The required number of wells, and cost per unit well, result in a costly system with an expected questionable payback period, when used to replace conventional fossil fuel based space heating. Vertical wells may be suited to cool "hot" subsurface reaction landfills in some situations. These installations would be cost prohibitive, if the goal were to cool an entire landfill back down to normal operating temperatures. A viable application of this technology could be installing a small array of wells focused on a limited area where elevated temperatures are first encountered. Cooling the waste in the initial "hot" area could prevent the heat and biological changes from spreading to the rest of the landfill.

- Horizontal loop GCHX systems are suited to installation in the waste during active landfilling. These systems can be installed at one or more levels and covered with incoming waste, ultimately positioning the loops within the central, hotter portion of the waste. These systems can be installed with manual labor at low cost and in a manner that efficiently extracts heat from the waste. A large flat 
area away from active operations is required for installation - a constraint that can present operating conflicts at some active landfills. Horizontal loop systems in the waste are subject to damage from waste settlement. Experience with horizontal gas collection system piping indicates many, if not most of the loops, will fail due to stress and displacement associated with waste settlement. It would not be possible to replace or repair the loops.

- Horizontal loop GCHX systems are also suited to installation on the landfill lining system during landfill cell construction. Installation of this type of system would be quick and inexpensive, and it does not conflict with site operations. Further, the loops are not subject to damage from settlement. Temperatures are lower at the base of the landfill than in the central portions of the waste. A system installed at the landfill base would therefore need to be larger than a comparable system installed within the waste to achieve the same level of heat recovery. Perhaps a compromise design would install the GCHX loops in the waste 3 to 6 meters above the lining system. Waste temperatures would be higher at these levels, and settlement could be tolerable considering the limited thickness of the underlying waste.

Open geothermal systems may also be viable for certain applications at a landfill site. Leachate pooled in collection sumps at the base of the landfill should have an elevated temperature similar to landfill base and waste areas. This fluid could be pumped directly from the sumps, processed through heat exchangers, and then recirculated back into the waste. Leachate flow rates may be a limiting factor in heat removal potential. Hydrologic Evaluation of Landfill Performance (HELP) Modeling (Author's experience) of solid waste sites indicates a typical 4-hectare landfill cell would generate on average about 60,000 liters per day, or about 40 liters per minute, over the course of a year. Leachate collection system flows are typically lower in the winter months due to freezing ground conditions, when heating demands are highest. A flow rate of over 250 liters per minute of a similarly heated fluid is required for a peak heating load necessary to heat four residences at the New Hampshire landfill [15•]. The 40 liter per minute leachate flow rate would limit applications to small and isolated structures that are not typically built with central heating systems, but rather heated with electric space heaters. At a landfill site, these structures would include leachate removal pump houses, or perhaps a gate house or scale house. The warm leachate could be efficiently circulated through a floor based radiant heating system to keep pipes from freezing in the pump stations and to heat the smaller spaces, or passed through a heat exchanger.

\section{Case Studies}

Although the presence of heat within landfills is well known, recovery and beneficial re-use of the heat has not been a common practice in the solid waste industry.

Cork, Ireland

The first known use of landfill heat recovery was in Cork, Ireland, where recovered heat is used for space heating of an administration building [16]. A horizontal closed loop system was installed in an inactive landfill in the year 2000. The piping is 2,400 meters long and the heat pump produces heat at the rate of $28 \mathrm{~kW}$. The system had a reported simple payback period of 4.5 to 6 years. Carbon dioxide emissions were reduced by $30 \%$ compared with a conventionally heated building.

\section{United Kingdom}

The potential for using geothermal heating system applications in a landfill was studied in the UK (http://www.golder. com/us/en/modules.php? name $=$ Newsletters $\&$ op $=$ viewarticle\&sp_id=172\&page_id=1086\&article_id=601). A trial horizontal closed loop system was installed in an inactive landfill. The piping was installed in direct contact with waste and leachate about 4 to 5 meters below the waste surface in a leachate extraction trench. The system was run for 49 hours and showed that the temperature of the carrier liquid was raised from $10^{\circ} \mathrm{C}$ to $20^{\circ} \mathrm{C}$, when pumped through the pipe loop. The study was intended to assess the feasibility of extracting heat from the landfill to replace fossil fuel-derived heat input in the landfill leachate treatment process.

\section{New Hampshire, USA}

A small scale landfill based geothermal heating system was installed in a landfill in New Hampshire, USA in 2011 [15•]. A horizontal closed loop GCHX was configured directly on the landfill base lining system during construction of a cell expansion. The system was designed to heat an adjacent 17 meters by 24 meters equipment maintenance garage, and melt snow and ice for approximately $185 \mathrm{~m}^{2}$ of truck scale approach ramps.

Waste disposal in the newly constructed cell commenced shortly after the GCHX was installed. The glycol/water fluid in the closed loop was periodically circulated and monitored for temperature as landfilling progressed. Fluid temperatures have held steady at about $20^{\circ} \mathrm{C}$ to $21^{\circ} \mathrm{C}$, indicating that the waste in the cell has yet to enter the final methanogenic phase of decomposition. A heat pump was installed in early winter 2013 to raise fluid temperatures, as $35^{\circ} \mathrm{C}$ fluid temperatures are required for direct heating purposes. The maintenance garage was heated throughout the 2013/2014 winter using heat recovered from the landfill. The incoming fluid 
temperatures did not drop over time as heat was removed from the landfill, indicating that at least for this relatively small system, the waste in the vicinity of the GCHX is producing enough heat to replace the removed heat. This contrasts with conventional geothermal systems where the ground typically cools to $0^{\circ} \mathrm{C}$ over the course of a heating season, and results in a highly efficient and economical operation. The landfill cell is equipped with leachate recirculation capability and initiation of recirculation is planned in the near future. A substantial increase in fluid temperatures is expected with the passage of time and the addition of moisture from recirculation. An expansion of the system to incorporate pavement radiant heating is planned in the near future.

The system cost about US $\$ 50,000$ to install and yearly savings of US $\$ 7,000$ are being realized, resulting in a simple payback period of 7 years. The savings came from the elimination of the heating fuel purchases and of the extra cost of electricity to operate the heat pump and circulation pumps. Approximately US $\$ 10,000$ of installation cost and US $\$ 3,000$ of annual electric costs would have been avoided if fluid temperatures were high enough to eliminate the need to operate the heat pump, reducing the payback period to four years. Approximately 10 tons per year of carbon emissions associated with burning fuel oil are eliminated by operating the landfill based geothermal heating system.

\section{Maryland, USA}

Owners of a commercial landfill in Maryland are currently proposing a green energy park as part of a landfill expansion proposal. The park would include wind turbines, photovoltaic solar panels, heat from combusting methane, and a landfill based geothermal heating system (http://www. connectionnewspapers.com/news/2014/feb/27/lortonlandfill-may-operate-until-2040/). Studies indicate these four renewable energy technologies can be integrated into landfill expansion plans and timed for cost-effective deployment [17].

\section{Conclusions}

Solid waste landfills produce substantial quantities of heat through biological waste decomposition and chemical reactions. The temperatures within municipal solid waste landfills have been observed to be in the range of $35^{\circ} \mathrm{C}$ to $60^{\circ} \mathrm{C}$, consistent with the optimum temperatures for anaerobic methanogenesis and the exothermic nature of that process. Landfills operated aerobically can have waste temperatures of $70^{\circ} \mathrm{C}$ or higher, but are operated in a temperature range of $40^{\circ} \mathrm{C}$ to $60^{\circ} \mathrm{C}$ through cooling by leachate recirculation, to minimize the risk of internal waste fires. WTE ash residual landfills have been observed to have maximum ash temperatures of about $70^{\circ} \mathrm{C}$, due to oxidation reduction reactions with metals in the ash, hydration of unreacted lime, and other unknown exothermic chemical reactions. Lastly, increasing numbers of MSW landfills are reported to have hot zones of waste, with landfill gas temperatures of $90^{\circ} \mathrm{C}$ or hotter. The cause of extreme heat generation in these landfills is not related to landfill fires and remains unknown, but is postulated to result from subsurface chemical reactions in certain waste types, and subsequent changes to the bacterial population in the waste.

Conventional ground based geothermal heating system principles can be applied to landfills to recover the waste heat. Vertical closed loop well systems can be drilled into existing landfilled waste, and horizontal closed loop systems can be installed at the base of a landfill during cell construction or within the waste during waste placement. The likelihood of return fluid temperatures in excess of $35^{\circ} \mathrm{C}$ is high, allowing for direct heating applications without the equipment and operating costs associated with use of a heat pump. Smaller open loop systems using leachate pooled in collection sumps are viable for use in small landfill structures such as pump stations and scale/guard houses. Lastly, limited vertical closed loop well systems could potentially play a role in controlling or eliminating subsurface reaction hot zones in waste, when deployed at the onset of this phenomenon.

Only two, relatively small, geothermal systems with a landfill heat source are known to have been installed. At these facilities, the economics of landfill waste heat recovery have been demonstrated to be highly favorable with short payback periods, and associated reductions in carbon emissions. A scaled-up version of these two installations at even a moderately sized landfill would appear to have sufficient heating capacity to serve adjacent large scale commercial/industrial facilities or greenhouses.

\section{Compliance with Ethics Guidelines}

Conflict of Interest Robert J. Grillo declares no conflict of interest.

Human and Animal Rights and Informed Consent This article does not contain any studies with human or animal subjects performed by the author.

\section{References}

Papers of particular interest, published recently, have been highlighted as:

- Of importance

1. Reinhart DR, Townsend TG. Landfill bioreactor design \& operation, CRC Press LLC; 1998. p. 16-18. 
2. Farquhar GJ. Landfill decomposition and gas/leachate generation processes. Seminar Documents from Sanitary Landfill Gas and Leachate Management; 1988.

3. Tchobanoglous G, Theisen H, Vigil SA. Integrated solid waste management: Engineering principals and management issues. New York: McGraw-Hill; 1993.

4. Cecchi F, Pavin P, Mussaco A, Mata-Alvarez J, Vallini G. Digesting the organic fraction of municipal solid waste: Moving from mesophilic $\left(37^{\circ} \mathrm{C}\right)$ to thermophilic $\left(55^{\circ} \mathrm{C}\right)$ conditions. Waste Manag Res. 1993;11:403-14.

5. Collins HJ. Impact of the temperature inside the landfill on the behavior of barrier systems, Proceeding 4th International Landfill Symposium, 1993:417-432.

6. Rowe RK. Long-term performance of contaminant barrier systems. 45th Rankine Lecture. Geotechnique. 2005;55(9):631-78.

7. Koerner GR, Koerner RM. In-situ temperature monitoring of geomembranes. Geosynth Inst. 2006.

8. Yesiller N, Hanson JL, Liu WL. Heat generation in municipal solid waste landfills. J Geotech Geoenviron Eng. 2005;131(11).

9. Hudgins M, Harper S. Operational characteristics of two aerobic landfill systems. The Seventh International Waste Management and Landfill Symposium. 1999. The first fully operational Aerobic Landfill began operation in Alberta, Canada in 2013, see footnote 10.

10. Musselman CN, Straub WA, Bidwell JN, Carpenter JE, Presher JR. Gas generation at a municipal waste combustor ash monofill Franklin, New Hampshire. Proceedings of the Air and Waste Management Association's 90th Annual Meeting, Toronto, Canada; 1997.
11. Klein R, Baumann T, Kahapka E, Niessner R. Temperature development in a modern municipal solid waste incineration (MSWI) bottom as landfill with regard to sustainable waste management. J Hazard Mater. 2001;83(3):265-80.

12. McGarry J, Walsh J, Huff R. Overview of managing MSW landfills with ongoing subsurface reactions. Presented at the 4th Global Waste Management Symposium, Orlando, Florida, USA; 2014. Information describing "hot" subsurface reaction landfills was first published in June 2014.

13. Almanza C, Bilgri T. Practical design and construction considerations for managing subsurface reactions at MSW landfills. Presented at the 4th Global Waste Management Symposium, Orlando, Florida, USA; 2014. Information describing "hot" subsurface reaction landfills was first published in June 2014.

14. Barlaz MA, Sadri A, Luettich S. Characterization of biological activity in refuse samples excavated from the Waimanalo Gulch sanitary landfill. Presented at the 4th Global Waste Management Symposium, Orlando, Florida, USA; 2014. Recently published laboratory study of bacteria behavior in waste subject to elevated temperatures.

15. Grillo RJ, Murray JS, Petersen J, Roy K. Landfill based geothermal system. Presented at the 3rd Global Waste Management Symposium, Phoenix, Arizona, USA; 2012. Only known heat recovery system installed in a modern lined landfill.

16. O'Connell S, Cassidy SF. Recent large scale ground-source heat pump installations in Ireland. Presented at the International Geothermal Conference, Reykjavik, Iceland; 2003.

17. Gupta R, Morris JF. Converting waste disposal sites to renewable energy sites using MSE berms, Geo-Congress 2013, CASCE 2013. 